\title{
Production of Guanosine by Psicofuranine and Decoyinine Resistant Mutants of Bacillus subtilis
}

\author{
Hiroshi Matsui, Katsuaki Sato, Hitoshi EnEI and Yoshio Hrrose \\ Central Research Laboratories of Ajinomoto Co., Inc., Kawasaki, Japan
}

Received March 6, 1979

\begin{abstract}
Growth of Bacillus subtilis AG169 that produced large amounts of xanthosine and guanosine was inhibited by psicofuranine. When AG169 was mutated to resistance against psicofuranine, a mutant, GP-1, which yielded more guanosine was obtained. Psicofuranine did not inhibit growth of GP-1 any more. The guanosine 5'-monophosphate (GMP) synthetase activities were then assayed. In GP-1, the specific activity decreased about half, the complete loss of repression by GMP was found, and the inhibition by GMP was slightly loosed, when compared with those of AG169.

Furthermore, as growth of GP-1 was strongly inhibited by decoyinine, decoyinine resistant mutants were derived from $G P-1$. Of these mutants, two strains, MG-1 and MG-4, were resistant to decoyinine completely and showed the exclusive accumulation of guanosine in high yields, i.e. 16.0 and $15.5 \mathrm{~g}$ of guanosine per liter with weight yields of 20.0 and $19.4 \%$ of consumed sugar, respectively. GMP synthetase activity of MG-1 increased remarkably in comparison with that of GP-1 or AG169, and the inhibitions by GMP, psicofuranine and decoyinine were completely released in MG-1. Namely, the psicofuranine and decoyinine resistances seemed to cause mainly variations of GMP synthetase, and as results, the conversion of xanthosine $5^{\prime}$-monophosphate (XMP) to GMP proceeded more smoothly, and a larger amount of guanosine was accumulated.
\end{abstract}

Many studies on microbial production of guanosine so far have been performed, but mutants with high productivity of guanosine have never been obtained. ${ }^{1 \sim 5}$ ) We have also already reported that we derived methionine sulfoxide resistant mutants from an inosineproducing strain of Bacillus subtilis, and obtained a mutant AG169 that did not excrete inosine but produced considerable amounts of xanthosine and guanosine. ${ }^{6)}$ But this mutant could not accumulate a sufficient amount of guanosine to be contented. In order to obtain mutants which accumulate further increased amounts of guanosine, it is necessary to derive mutants that convert XMP to GMP more smoothly, i.e. are released from regulation of GMP synthetase. We then tried derivation of psicofuranine and decoyinine resistant mutants from AG169.

Psicofuranine (angustmycin C) and decoyinine (angustmycin A) have been found as antibiotics that Streptomyces hygroscopicus produces. ${ }^{7 q}$ And they are structual analogs of adenosine. ${ }^{10,11)}$ They inhibit not only ribosephosphate pyrophosphokinase (EC 2.7.6.1) reaction, ${ }^{12)}$ but also mainly GMP synthetase reaction, and the mode of action is regarded as non-competitive inhibition of GMP synthetase. ${ }^{13 \sim 20)}$

At first, we obtained a psicofuranine resistant mutant that produced more guanosine and less xanthosine than the parent AG169. Nextly, we obtained decoyinine resistant mutants from the psicofuranine resistant mutant. One of them produced a larger amount of guanosine exclusively. The present paper deals with derivation of improved guanosine-producing mutants and clarification of some of their properties, especially correlation between psicofuranine or decoyinine resistance and GMP synthetase activity.

\section{MATERIALS AND METHODS}

Bacterial strains. Psicofuranine or decoyinine resistant mutants were derived from a xanthosine- and 
guanosine-producing strain of $B$. subtilis, AG169. AG169 is a histidine auxotroph, and is genetically lacking GMP reductase (EC 1.6.6.8) and succinoadenosine 5'-monophosphate (succino-AMP) synthetase (EC 6.3.4.4), and is resistant to methionine sulfoxide. ${ }^{\text {) }}$

Chemicals. Psicofuranine and decoyinine were obtained from the Upjohn Company.

Culture media. Medium 1 contained $10 \mathrm{~g}$ of polypeptone, $10 \mathrm{~g}$ of yeast extract, $5 \mathrm{~g}$ of $\mathrm{NaCl}, 5 \mathrm{~g}$ of glucose and distilled water, in a total volume of 1 liter. The $\mathrm{pH}$ was adjusted to 7.0 with $\mathrm{NaOH}$. Medium 2 contained $20 \mathrm{~g}$ of glucose, $5 \mathrm{~g}$ of $\mathrm{NH}_{4} \mathrm{Cl}, 4 \mathrm{~g}$ of $\mathrm{KH}_{2} \mathrm{PO}_{4}$, $0.2 \mathrm{~g}$ of $\mathrm{MgSO}_{4} \cdot 7 \mathrm{H}_{2} \mathrm{O}, 0.01 \mathrm{~g}$ of $\mathrm{FeSO}_{4} \cdot 7 \mathrm{H}_{2} \mathrm{O}, 0.01 \mathrm{~g}$ of $\mathrm{MnSO}_{4} \cdot 4 \mathrm{H}_{2} \mathrm{O}, 0.5 \mathrm{~g}$ of sodium citrate, $1 \mathrm{~g}$ of Lglutamic acid, $0.5 \mathrm{~g}$ of L-histidine, $0.1 \mathrm{~g}$ of adenine and distilled water, in a total volume of 1 liter. The $\mathrm{pH}$ was adjusted to 7.0 with $\mathrm{KOH}$. Medium 3 contained $80 \mathrm{~g}$ of glucose, $15 \mathrm{~g}$ of $\mathrm{NH}_{4} \mathrm{NO}_{3}, 0.2 \mathrm{~g}$ of $\mathrm{KH}_{2} \mathrm{PO}_{4}$, $0.4 \mathrm{~g}$ of $\mathrm{MgSO}_{4} \cdot 7 \mathrm{H}_{2} \mathrm{O}, 0.01 \mathrm{~g} \mathrm{FeSO} \cdot{ }_{4} \cdot 7 \mathrm{H}_{2} \mathrm{O}, 0.01 \mathrm{~g}$ of $\mathrm{MnSO}_{4} \cdot 4 \mathrm{H}_{2} \mathrm{O}, 2 \mathrm{~g}$ of $\mathrm{CaCl}_{2} \cdot 2 \mathrm{H}_{2} \mathrm{O}, 0.3 \mathrm{~g}$ of DL-methionine, $10 \mathrm{~g}$ of $\mathrm{L}$-glutamic acid, $0.3 \mathrm{~g}$ of $\mathrm{L}$-histidine, $40 \mathrm{ml}$ of Ajieki (soybean hydrolysate), $1.4 \mathrm{~g}$ of ribonucleic acid (RNA), $15 \mathrm{~g}$ of $\mathrm{CaCO}_{3}$ and distilled water, in a total volume of 1 liter. The $\mathrm{pH}$ was adjusted to 7.5 with $\mathrm{KOH}$. Calcium carbonate was sterilized separately.

Derivation of mutants. Cells $\left(1 \times 10^{9}\right.$ to $\left.5 \times 10^{9}\right)$ from the logarithmic growth phase in medium 1 were harvested, washed with $50 \mathrm{~mm} \quad \mathrm{KH}_{2} \mathrm{PO}_{4}-\mathrm{K}_{2} \mathrm{HPO}_{4}$ buffer (pH 7.0) and exposed to $500 \mu \mathrm{g}$ of $N$-methyl$N^{\prime}$-nitro- $N$-nitrosoguanidine (NG) per $\mathrm{ml}$ in the same phosphate buffer for $50 \mathrm{~min}$ in an ice bath. The NGtreated cells were washed with the same phosphate buffer, diluted and spread on medium 2 agar plates supplemented with psicofuranine or decoyinine. After incubation for 2 to 5 days at $34^{\circ} \mathrm{C}$, colonies appeared on the plates were picked up. In derivation of spontaneous mutants, the method was the same as described above except that NG-treatment was omitted.

Fermentation tests. Cells that grew overnight on medium 1 agar plates were inoculated into $20 \mathrm{ml}$ of medium 3 in a $500 \mathrm{ml}$-flask. After cultivation for $72 \mathrm{hr}$ at $34^{\circ} \mathrm{C}$ with shaking, $10 \mu \mathrm{I}$ of culture broth was spotted on filter paper (Toyo Roshi No. 51). After separation by paperchromatography, using isopropanol-ammoniawater $(7: 2: 1)$ as a solvent, inosine, xanthosine and guanosine were extracted from the paper with $10 \mathrm{ml}$ of $0.1 \mathrm{~N} \mathrm{HCl}$ for $5 \mathrm{hr}$ at room temperature and were estimated spectrophotometrically.

Growth inhibition tests. Bacterial cells grown overnight in $3 \mathrm{ml}$ of medium 2 in a test tube were washed with $50 \mathrm{~mm} \quad \mathrm{KH}_{2} \mathrm{PO}_{4}-\mathrm{K}_{2} \mathrm{HPO}_{4}$ buffer (pH 7.0) and about $10^{6}$ cells were inoculated into $3 \mathrm{ml}$ of medium 2 supplemented with psicofuranine or decoyinine. Growth was measured by absorbance at $540 \mathrm{~nm}$ after culturing for $24 \mathrm{hr}$ at $34^{\circ} \mathrm{C}$.

Enzyme preparation. Cells that had grown overnight on medium 1 agar plates were transferred to $20 \mathrm{ml}$ of the inoculum medium, the composition being the same as medium 3 except that $\mathrm{CaCO}_{3}$ was omitted. In special cases, purine bases (adenine or guanine) were used instead of RNA. After cultivation for 16 to $20 \mathrm{hr}$ at $34^{\circ} \mathrm{C}$, cells were harvested from culture broth by centrifugation, washed twice with a $0.85 \% \mathrm{NaCl}$ solution containing $0.1 \mathrm{M}$ ethylenediaminetetraacetic acid and three times with chilled acetone, and were dried in a vacuum.

Enzyme activity assay. GMP synthetase (EC 6.3. 5.2) activity was assayed by the method of Moyed and Magasanik. ${ }^{21)}$ The reaction mixture contained $3 \mu$ mol of $5^{\prime}$-XMP, $20 \mu \mathrm{mol}$ of L-glutamine, $2 \mu \mathrm{mol}$ of adenosine 5'-triphosphate (ATP), $24 \mu \mathrm{mol}$ of $\mathrm{MgCl}_{2}$, $120 \mu \mathrm{mol}$ of Tris- $\mathrm{HCl}$ buffer ( $\mathrm{pH} \mathrm{8.0)}$, and the enzyme in a total volume of $0.5 \mathrm{ml}$. The reaction was carried out at $37^{\circ} \mathrm{C}$ for 30 min with gentle shaking and stopped by the addition of $3 \mathrm{ml}$ of $3 \%$ perchloric acid. The amount of GMP formed was determined by measuring absorbance at $290 \mathrm{~nm}$ spectrophotometrically. In one case, the reaction was stopped by boiling for $3 \mathrm{~min}$, and the amount of glutamic acid formed was determined by measuring absorbance at $340 \mathrm{~nm}$ with the use of glutamic acid dehydrogenase (EC 1.4.1.3) and nicotinamide adenine dinucleotide. Specific activity of enzyme was expressed as nanomoles of GMP or glutamic acid formed per minute per milligram of dried cells.

\section{RESULTS}

Growth inhibition of strain AG169 by psicofuranine and decoyinine, and recovery of the inhibition by guanine and xanthine

Growth of AG169 on medium 2 was inhibited remarkably by additions of 0.5 and $1.0 \mathrm{mg}$ of psicofuranine or decoyinine per $\mathrm{ml}$. The growth inhibition was reversed completely by 0.1 and $0.5 \mathrm{mg}$ of guanine per $\mathrm{ml}$, but not by $0.5 \mathrm{mg}$ of xanthine per $\mathrm{ml}$. The result is presented in Table $\mathrm{I}$.

\section{Derivation of psicofuranine or decoyinine re- sistant mutants from strain AG169 and their guanosine productivity}

Mutants resistant to 0.5 and $1.0 \mathrm{mg}$ of psico- 
Table I. Growth Inhibition of Strain AG169 by Psicofuranine and Decoyinine and

RECOVERY OF THE INHIBITION BY GuANINE AND Xanthine

\begin{tabular}{crrrrc}
\hline & \multicolumn{4}{c}{ Growth response (\%) } \\
\cline { 2 - 5 } $\begin{array}{c}\text { Inhibitors } \\
(\mathrm{mg} / \mathrm{ml})\end{array}$ & & None & \multicolumn{2}{c}{$\begin{array}{c}\text { Guanine } \\
(\mathrm{mg} / \mathrm{ml})\end{array}$} & $\begin{array}{c}\text { Xanthine } \\
(\mathrm{mg} / \mathrm{ml})\end{array}$ \\
\cline { 3 - 5 } & & & 0.1 & 0.5 & 0.5 \\
\hline None & & 100 & 115 & 105 & 130 \\
Psicofuranine & 0.5 & 10 & 95 & 100 & 15 \\
& 1.0 & 5 & 91 & 98 & 10 \\
Decoyinine & 0.5 & 5 & 103 & 108 & 8 \\
& 1.0 & 2 & 100 & 105 & 2 \\
\hline
\end{tabular}

furanine or decoyinine per $\mathrm{ml}$ were derived from AG169. Mutants improved in guanosine productivity were obtained from these psicofuranine resistant mutants with a frequency of $2 \%$ ( 4 of 200 colonies), but were not obtained from decoyinine resistant mutants at all ( 0 of 200 colonies). The parent AG169 accumulated $8.0 \mathrm{~g}$ of guanosine and $6.0 \mathrm{~g}$ of xanthosine per liter at an optimal RNA concentration. The best psicofuranine resistant mutant $\mathrm{GP}-1$ accumulated $10.6 \mathrm{~g}$ of guanosine and $3.4 \mathrm{~g}$ of xanthosine per liter (Table III). When growth inhibition of GP-1 by psicofuranine was examined, GP-1 was not inhibited by 0.5 to $2.0 \mathrm{mg}$ of psicofuranine per $\mathrm{ml}$ at all (Fig. 1).

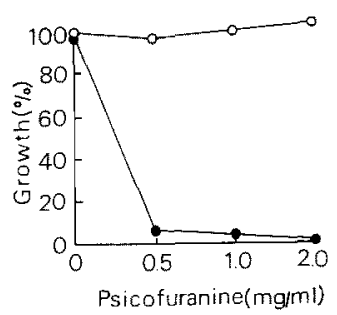

FIG. 1. Growth Inhibition of Psicofuranine Resistant Mutant GP-1 and the Parent AG169 by Psicofuranine. O-O, GP-1; - A AG169.

Growth inhibition of strain $G P-I$ by decoyinine, and recovery of the inhibition by guanine and xanthine

Furthermore, growth inhibition of the psicofuranine resistant mutant GP-1 by decoyinine was examined. Growth of GP-1 on medium 2 was inhibited strongly by the additions of 0.5 , 1.0 and $2.0 \mathrm{mg}$ of decoyinine per $\mathrm{ml}$. The growth inhibition was reversed completely by $0.5 \mathrm{mg}$ of guanine per $\mathrm{ml}$, but not by $0.5 \mathrm{mg}$ of xanthine per $\mathrm{ml}$ (Table II). This result was the same as the case of AG169 (Table I).

Table 1I. Growth Inhibition of Strain GP-1 BY DeCOYININE AND ReCOVERY OF THE INHIBITION by Guanine and XanthIne

\begin{tabular}{lrrrr}
\hline \multirow{2}{*}{$\begin{array}{l}\text { Inhibitor } \\
(\mathrm{mg} / \mathrm{ml})\end{array}$} & & \multicolumn{3}{c}{ Growth response (\%) } \\
\cline { 3 - 5 } & & None & $\begin{array}{c}\text { Guanine } \\
(\mathrm{mg} / \mathrm{ml}) \\
0.5\end{array}$ & $\begin{array}{c}\text { Xanthine } \\
(\mathrm{mg} / \mathrm{ml})\end{array}$ \\
\hline None & & 100 & 100 & 100 \\
Decoyinine & 0.1 & 70 & 100 & 60 \\
& 0.5 & 0 & 105 & 0 \\
& 1.0 & 0 & 110 & 0 \\
& 2.0 & 0 & 100 & 0 \\
\hline
\end{tabular}

Derivation of decoyinine resistant mutants from strain $G P-1$ and their guanosine productivity

Mutants resistant to $1.0 \mathrm{mg}$ of decoyinine per $\mathrm{ml}$ were derived from GP-1. Decoyinine resistant mutants appeared spontaneously. at the frequency of 0.5 to 1.0 colony per $10^{5}$ cells of GP-1. In the accumulation patterns of purine nucleosides, 22 of 56 strains produced guanosine exclusively, 30 of 56 strains produced guanosine and xanthosine like the parent, 2 of 56 strains produced guanosine and inosine, and 2 of 56 strains produced xanthosine only. Here, five mutants were selected as those that produced more guanosine than the parent. The best mutant MG-1 accumulated $16.0 \mathrm{~g}$ of guanosine per liter in a weight yield of $20.0 \%$ of consumed sugar. Another mutant MG-4 accumulated $15.5 \mathrm{~g}$ of guanosine per liter in a weight yield of $19.4 \%$ of consumed sugar. They did not accumulate inosine and xanthosine. The result is shown in Table III.

Growth inhibition of GP-1, MG-1 and MG 41 by decoyinine was examined. $\mathrm{MG}-1$ was resistant to $0.5,1.0$ and $2.0 \mathrm{mg}$ of decoyinine per $\mathrm{ml}$. MG-41 that still produced xanthosine was more slightly resistant than the parent GP-1 at $0.5 \mathrm{mg}$ of decoyinine per $\mathrm{ml}$, but was sensitive to 1.0 and $2.0 \mathrm{mg}$ of decoyinine per $\mathrm{ml}$ like the parent (Fig. 2). The 
Table III. Guanosine Productivity of Decoyinine Resistant Mutants DERIVED FROM GP-1

The resistance to decoyinine was investigated as described in growth inhibition tests. It was not investigated beyond $2.0 \mathrm{mg}$ of decoyinine per $\mathrm{ml}$.

\begin{tabular}{lccccc} 
& $\begin{array}{c}\text { Degree } \\
\text { of }\end{array}$ & \multicolumn{4}{c}{ Productivity (g/liter) } \\
\cline { 4 - 6 } $\begin{array}{c}\text { Strain } \\
\text { decoyinine } \\
\text { resistance } \\
(\mathrm{mg} / \mathrm{ml})\end{array}$ & $\begin{array}{c}\text { Ino- } \\
\text { sine }\end{array}$ & $\begin{array}{c}\text { Xantho- Guano- } \\
\text { sine }\end{array}$ & $\begin{array}{c}\text { Total } \\
\text { sine } \\
\text { purine } \\
\text { nucleoside }\end{array}$ \\
\hline GP-1 & - & 0 & 3.4 & 10.6 & 14.0 \\
MG-1 & 2.0 & 0 & 0 & 16.0 & 16.0 \\
MG-4 & 2.0 & 0 & 0 & 15.5 & 15.5 \\
MG-7 & 1.0 & 0 & 1.2 & 12.2 & 13.4 \\
MG-36 & 0.5 & 0 & 2.1 & 12.2 & 13.1 \\
MG-41 & 0.5 & 0 & 2.5 & 11.8 & 14.3 \\
\hline
\end{tabular}

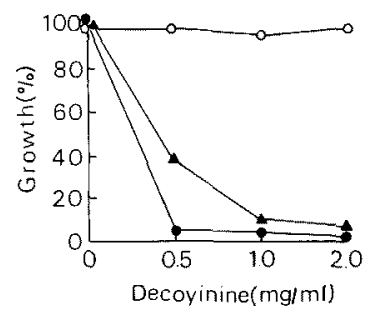

FIG. 2. Growth Response of Decoyinine Resistant Mutants and the Parent to the Effect of Decoyinine. ○-O, MG-1 (mutant); $\mathbf{A}-\mathbf{\Lambda}, \mathbf{M G}-41$ (mutant); - - GP-1 (parent).

variation of accumulation from xanthosine to guanosine responded to the degree of decoyinine resistance (Table III).

$G M P$ synthetase activity and its inhibition by $G M P$ in strains $A G 169, G P-1$ and $M G-1$

As it is known that psicofuranine and decoyinine inhibit non-competitively GMP synthetase activity, the enzyme of psicofuranine and decoyinine resistant mutants was investi-
Table IV. GMP Synthetase Activity and Its Inhibition BY GMP IN STrains AG169, GP-1 AND MG-1

\begin{tabular}{|c|c|c|c|}
\hline \multirow[t]{2}{*}{ Strain } & \multicolumn{3}{|c|}{$\begin{array}{c}\text { Specific activity of } \\
\text { GMP synthetase } \\
\text { (nmol/min per mg of dried cells) }\end{array}$} \\
\hline & $\begin{array}{c}\text { No } \\
\text { addition }\end{array}$ & $\begin{array}{c}0.6 \mathrm{mM} \\
\mathrm{GMP}\end{array}$ & $\begin{array}{l}4 \mathrm{mM} \\
\mathrm{GMP}\end{array}$ \\
\hline $\begin{array}{l}\text { AG169 (parent) } \\
\text { GP-1 }\end{array}$ & 0.563 & 0.560 & 0.450 \\
\hline (psicofuranine $^{r}$ ) & 0.270 & 0.260 & 0.240 \\
\hline $\begin{array}{c}\text { MG-1 (psicofura } \\
\text { decoyinine }{ }^{r} \text { ) }\end{array}$ & $\mathrm{e}^{r}$ & 0.755 & 0.762 \\
\hline
\end{tabular}

gated. As shown in Table IV, specific activity of GMP synthetase of the psicofuranine resistant mutant GP-1 decreased half of that of the parent AG169. In the psicofuranine and decoyinine resistant mutant $M G-1$, the specific activity increased remarkably when compared with those of AG169 and GP-1. And the mutants GP-1 and MG-1 did not respond to GMP in the same manner as the parent AG169.

Inhibition of GMP synthetase activity by psicofuranine, decoyinine and adenosine in strains $A G 169, G P-1$ and $M G-1$

Psicofuranine and decoyinine are analogs of adenosine. Here, inhibition of GMP synthetase activity by psicofuranine, decoyinine and adenosine was investigated. GMP synthetase activity of the parent AG169 was inhibited strongly by 2.2 and $4.4 \mathrm{~mm}$ psicofuranine, decoyinine and adenosine. In the psicofuranine resistant mutant GP-1, the inhibition by psicofuranine and adenosine decreased considerably, but the inhibition by decoyinine did not vary. In the psicofuranine and decoyinine resistant mutant $\mathrm{MG}-1$, the inhibition was lost

Table V. Inhibition of GMP Synthetase Activity by Psicofuranine, Decoyinine and Adenosine in Strains AG169, GP-1 and MG-1

\begin{tabular}{|c|c|c|c|c|c|c|c|}
\hline \multirow{3}{*}{ Strain } & \multicolumn{7}{|c|}{ Relative activity of GMP synthetase ( $\%$ ) } \\
\hline & \multirow{2}{*}{ None } & \multicolumn{2}{|c|}{ Psicofuranine } & \multicolumn{2}{|c|}{ Decoyinine } & \multicolumn{2}{|c|}{ Adenosine } \\
\hline & & $2.2 \mathrm{~mm}$ & $4.4 \mathrm{~mm}$ & $2.2 \mathrm{~mm}$ & $4.4 \mathrm{~mm}$ & $2.2 \mathrm{mM}$ & $4.4 \mathrm{~mm}$ \\
\hline AG169 & 100 & 60 & 45 & 50 & 40 & 30 & 20 \\
\hline GP-1 & 100 & 80 & 80 & 40 & 40 & 80 & 40 \\
\hline $\mathrm{MG}-1$ & 100 & 100 & 100 & 100 & 100 & 100 & 100 \\
\hline
\end{tabular}


completely. The result is presented in Table $\mathrm{V}$.

\section{GMP synthetase activity of strains AG169, $G P-1$ and $M G-1$ under the condition of adding guanine to culture medium}

GMP synthetase activity was assayed under the condition of culturing in the medium, the composition being the same as medium 3 except that $\mathrm{CaCO}_{3}$ was omitted and purine bases instead of RNA were used. In the parent AG169, the slight decrease of enzyme activity was observed by adding $500 \mathrm{mg}$ of guanine per liter to the above culture medium. In GP-1 and MG-1, the enzyme repression by GMP was removed completely because the decrease of enzyme activity by adding $3.3 \mathrm{~mm}$ guanine to the culture medium was not found (Table VI).

\section{DISCUSSION}

We have tried improvement of mutants which produce guanosine in a high yield. ${ }^{5,6}$ It will become a very useful method of our purpose to derive psicofuranine or decoyinine resistant mutants from a xanthosine- and guanosine-producing strain AG169, for it is thought that accumulation of a large amount of xanthosine depends on insufficiency of deregulation of GMP synthetase. Therefore, growth inhibition of AG169 by psicofuranine or decoyinine, and its recovery by guanine or xanthine were examined. The growth was markedly inhibited by 0.5 and $1.0 \mathrm{mg}$ of psicofuranine or decoyinine per $\mathrm{ml}$ (Table I). The growth inhibition was reversed completely by 0.1 and $0.5 \mathrm{mg}$ of guanine per $\mathrm{ml}$, but not by $0.5 \mathrm{mg}$ of xanthine per $\mathrm{ml}$ (Table I). This result implies that psicofuranine or decoyinine does not disturb ribosephosphate pyrophosphokinase, but GMP synthetase. When psicofuranine or decoyinine resistant mutants were derived from AG169, improved guanosine producers were obtained with a frequency of $2 \%$ in psicofuranine resistant mutants. The best mutant GP-1 accumulated $10.6 \mathrm{~g}$ of guanosine and $3.4 \mathrm{~g}$ of xanthosine per liter
(Table III). On the other hand, any improved guanosine producers were not found in the decoyinine resistant mutants of AG169. The reason is probably that anyone of the mutants was not resistant to decoyinine completely. Growth of GP-1 was not prevented by 0.5 to $2.0 \mathrm{mg}$ of psicofuranine per $\mathrm{ml}$ at all (Fig. 1), but was still inhibited completely by 0.5 to $2.0 \mathrm{mg}$ of decoyinine per $\mathrm{ml}$ (Table III). From these facts, the effect of decoyinine on GMP synthetase may be slightly different from that of psicofuranine. When further mutation to decoyinine from GP-1 was performed spontaneously, decoyinine resistant mutants appeared at the ratio of 0.5 to 1.0 colony per $10^{5}$ cells of GP-1. The best mutant $\mathrm{MG}-1$ did not accumulate inosine and xanthosine, but accumulated $16.0 \mathrm{~g}$ of guanosine per liter in a weight yield of $20 \%$ of consumed sugar (Table III). Growth of MG-1 was not inhibited completely by 0.5 to $2.0 \mathrm{mg}$ of decoyinine per $\mathrm{ml}$ (Fig. 2). Incomplete decoyinine resistant mutant MG-41 could not convert all of xanthosine to guanosine (Table III, Fig. 2). Thus, our purpose of obtaining a mutant which accumulates guanosine exclusively with high productivity was achieved by the psicofuranine and decoyinine resistant mutant $\mathrm{MG}-1$.

The correlation between psicofuranine or decoyinine resistance and GMP synthetase activity was investigated in three strains of AG169, GP-1 and MG-1. Although the specific activity of GMP synthetase of GP-1 reduced approximately $50 \%$ when compared with that of AG169, that of MG-1 increased $35 \%$ of that of AG169 (Table IV). Inhibition of GMP synthetase activity by 4 mM GMP was observed at the degree of approximately 20 and $10 \%$ in AG169 and GP-1, respectively, but was not found in MG-1 at all (Table IV). Inhibition by psicofuranine or decoyinine in AG169 was found at the degree of about $40 \sim$ $60 \%$. Inhibition by psicofura- nine in GP-1 was lost considerably when compared with that of AG169, but inhibition by decoyinine was similar to that of $A G 169$. In MG-1, the inhibitions were not observed at all (Table V). Furthermore, repression of GMP synthetase 
by GMP ( $3.3 \mathrm{~mm}$ as guanine in the culture medium) was not found in GP-1 and MG-1. In the parent AG169, it was slightly recognized (Table VI).

Table VI. GMP Synthetase Activity of Strains AG169, GP-1 AND MG-1 UNDER tHe CONDITION of Adding Guanine to Culture Medium

The cell cultures were carried out by using adenine or guanine instead of RNA in medium 3.

\begin{tabular}{ccc} 
Strain & \multicolumn{2}{c}{$\begin{array}{c}\text { Specific activity of GMP synthetase } \\
\text { (nmol/min per mg of dried cells) }\end{array}$} \\
\cline { 2 - 3 } & $\begin{array}{c}\text { Adenine } \\
50 \mathrm{mg} / \text { liter }\end{array}$ & $\begin{array}{c}\text { Adenine } 50 \mathrm{mg} / \text { liter } \\
+ \text { Guanine } \\
500 \mathrm{mg} / \text { liter }(3.3 \mathrm{~mm} \text { ) }\end{array}$ \\
\hline AG169 & 0.535 & $\mathbf{0 . 5 0 5}$ \\
GP-1 & 0.330 & $\mathbf{0 . 3 4 5}$ \\
MG-1 & 0.680 & 0.693 \\
\hline
\end{tabular}

From above data, we could not conclude why GP-1 or MG-1 accumulated a larger amount of guanosine than AG169. However, in GP-1, the slight loss of inhibition or repression by GMP might cause further conversion from XMP to GMP. In MG-1, the loss of inhibition by GMP and increase of specific activity might cause smoothly conversion to GMP without pooling XMP intracellularly. Or the loss of sensitivity to psicofuranine and decoyinine in GMP synthetase might be related to the guanosine production in mechanism different from deregulation of GMP synthetase by GMP.

Acknowledgments. We thank Drs. M. Takahashi, H. Okada, T. Shiro and K. Takinami of the Central Research Laboratories, Ajinomoto Company, Inc.,
Kawasaki, Japan, for their encouragement during the course of this work.

\section{REFERENCES}

1) I. Nogami, M. Kida, I. Iijima and M. Yoneda, Agric. Biol. Chem., 32, 144 (1968).

2) S. Konishi and T. Shiro, ibid., 32, 396 (1968).

3) H. Momose and I. Shiio, J. Gen. Appl. Microbiol., 15, 399 (1969).

4) K. Komatsu, A. Saijo, R. Kodaira and T. Osawa, Hakko To Taisha, 22, 54 (1970).

5) H. Matsui, K. Sato, H. Enei and Y. Hirose, Agric. Biol. Chem., 42, 637 (1978).

6) H. Matsui, K. Sato, H. Enei and Y. Hirose, Appl. Environ. Microbiol., 34, 337 (1977).

7) H. Yüntsen, H. Yonehara and H. Ui, J. Antibiot., A7, 113 (1954).

8) H. Sakai, H. Yüntsen and F. Ishikawa, ibid., A7, 116 (1954).

9) K. Kikuchi, ibid., A8, 145 (1955).

10) H. Yüntsen, ibid., A11, 233 (1958).

11) H. Yüntsen, ibid., A11, 244 (1958).

12) A. Bloch and C.A. Nichol, Biochem. Biophys. Res. Commun., 16, 400 (1964).

13) L. Slechta, ibid., 3, $596(1960)$.

14) N. Tanaka, J. Antibiot., 16, 163 (1963).

15) S. Udaka and H. S. Moyed, J. Biol. Chem., 238, 2797 (1963).

16) H. Kuramitsu and H. S. Moyed, Biochim. Biophys. Acta, 85, 504 (1964).

17) T. T. Fukuyama and H. S. Moyed, Biochemistry, 3, 1488 (1964).

18) H. Kuramitsu and H. S. Moyed, J. Biol. Chem., 241, 1596 (1966).

19) T. T. Fukuyama, ibid., 241, 4745 (1966).

20) T. Spector and L. M. Beacham, ibid., 250, 3101 (1975).

21) H. S. Moyed and B. Magasanik, ibid., 226, 351 (1957). 